\title{
PARTISIPASI MASYARAKAT DALAM PROGRAM PEMBERIAN ASI EKSLUSIF DI TEMANGGUNG
}

\author{
C.Ermayani Putriyanti \\ Akademi Keperawatan Ngesti Waluyo \\ Korespondensi penulis: ermayani.putriyanti@gmail.com
}

\begin{abstract}
Abstrak
ASI ekslusif bukan hanya meningkatkan daya tahan tubuh, menurunkan angka kematian bayi dan balita akibat diare dan infeksi saluran nafas. Ada hubungan antara pemberian ASI ekslusif dengan tingginya tingkat intelegensi anak, penghasilan meningkat ketika berusia 30 tahun, serta mencegah kanker di kemudian hari. Dampak menyusui mengurangi perdarahan pasca melahirkan, mencegah kanker payudara dan kanker ovarium. Penelitian ini bertujuan mengetahui partisipasi masyarakat dalam program pemberian ASI ekslusif di wilayah kerja Puskesmas Parakan. Data diperoleh dengan melakukan wawancara mendalam, observasi dan dokumentasi. Partisipasi masyarakat dalam mendukung ASI ekslusif belum maksimal, belum ada pengembangan strategi baru terkait program ASI ekslusif, masyarakat belum dilibatkan dalam perencanaan program, belum ada alokasi dana khusus untuk kegiatan program ASI ekslusif. Penyebab kegagalan ASI paling tinggi pada ibu bekerja dan keluarga terutama nenek. Partisipasi masyarakat perlu ditingkatkan melalui kerjasama dengan tokoh masyarakat, tokoh agama, karang taruna dalam sosialisasi ASI ekslusif. Perlunya ada kebijakan pengalokasian dana desa untuk sosialisasi ASI ekslusif, pengetahuan kader terkait ASI ekslusif lebih ditingkatkan, agar kader bisa melakukan penyuluhan dan tidak sekedar mengingatkan saja. Perlunya kerjasama dengan perusahan atau pabrik terkait kebijakan menyediakan ruangan untuk memerah dan menyusui bayi.
\end{abstract}

Kata Kunci : partisipasi masyarakat; program ASI ekslusif

\section{PENDAHULUAN}

Kesehatan

merupakan indikator penting dalam mewujudkan kemajuan bangsa. Masih banyaknya permasalahan kesehatan yang harus diatasi oleh bangsa Indonesia.Angka kematian ibu sudah mengalami penurunan, namun masih jauh dari target MGDs (Millenium Development Goals) 2015. Adapun 1 dari 25 anak di Indonesia meninggal sebelum mereka berusia 5 tahun. Angka kematian bayi dan balita di Indonesia dalam 5 tahun terakhir memang mengalami penurunan yang signifikan, namun demikian masih terjadi disparitas regional pencapaian target, yang mencerminkan adanya perbedaan dalam pelayanan kesehatan dan masih tinggi bila dibandingkan Negara ASEAN lainnya. Selain itu penurunan angka kematian bayi dan balita di Indonesia, memang belum sesuai dengan target MDGs (Millenium Development Goals) 2015, yang menargetkan untuk AKB (Angka Kematian Bayi) sebesar 23 per 1000 kelahiran hidup, saat ini pada posisi 32 per 1000 kelahiran hidup. Sedangkan untuk AKBa (Angka Kematian Balita) sebesar 40 per 1000 kelahiran hidup, target yang ditetapkan adalah 32 per 1000 kelahiran hidup. Adapun penyebab kematian $\mathrm{AKB}$ dan AKBa adalah 
pneumonia, diare dan gizi kurang yang berdampak balita kurus dan pendek.

Diare dan pneumonia merupakan penyakit pembunuh bayi dan balita di dunia. Meningkatnya prosentase kematian pada anak kurang dari 5 tahun sampai dengan $44 \%$ perlu mendapatkan penanganan yang serius agar anak dapat diselamatkan dan tumbuh sehat (Lancet, 2015). Masalah diare dan pneumonia juga merupakan penyakit pembunuh anak di Indonesia. Menurut Utami Roesli jika semua bayi di dunia segera setelah lahir diberi kesempatan menyusu sendiri dengan membiarkan kontak kulit ibu ke kulit bayi setidaknya selama satu jam ada satu juta bayi dapat diselamatkan. Selain itu ASI dapat meningkatkan daya tahan tubuh bayi, agar terhindar dari muntah dan mencret, penyakit saluran pernapasan, kanker pada anak (limfoma maligna. Hodgkin,leukemia, neurobalstoma), sepsis dan meningitis. Kolostrum mengandung zat kekebalan 10-17 kali dari susu matang (matur), sehingga dapat melindungi bayi dari diare, gangguan pernapasan, batuk, pilek, masalah alergi dan infeksi telinga. Penelitian Jones Lancet dan K. Edmond (2003) bahwa bayi yang diberi ASI dapat menekan kematian bayi sebesar $13 \%$, pemberian vitamin A hanya $2 \%$ dan pemberian Zinc $5 \%$.

Menurut laporan Unicef (2014), hanya $42 \%$ bayi-bayi di Indonesia yang mendapatkan ASI ekslusif sampai dengan 6 bulan dan $37 \%$ anak di bawah lima tahun mengalami kurang gizi yang ditandai stunting (pendek). Pada UndangUndang No. 36 Tahun 2009, dinyatakan bahwa bayi kurang dari 6 bulan berhak mendapatkan ASI dari ibunya kecuali ada indikasi medis. Masih rendahnya cakupan ASI ekslusif di Indonesia, mengambarkan hanya sedikit anak Indonesia yang memperoleh kecukupan nutrisi dari ASI. Padahal ASI sangat merupakan nutrisi yang penting untuk proses tumbuh kembang anak dan pengaruh jangka panjangnya. Tingginya stunting atau anak pendek di Indonesia saat ini menunjukkan, kurang gizi yang kronis pada anak sejak usia dini. Menurut Cesar G Victora (2015) bayi yang mendapatkan ASI ekslusif ada hubungan dengan tingkat intelegensi, lebih baik dalam tahun tahun belajarnya dan meningkat penghasilannnya ketika berusia 30 tahun.

Menyusui memiliki dampak positif bagi ibu maupun bayi., Alison Stuebe (2009) menyatakan bahwa bayi yang tidak disusui secara ekslusif memiliki resiko tinggi mengalami, infeksi, obesitas, diabetes tipe I dan 2, leukemia dan sindrome mati secara mendadak. ibu yang tidak menyusui memiliki resiko tinggi mengalami menoupose lebih dini, kanker payudara, kanker ovarium, diabetes tipe 2, miocard infark dan sindrome metabolic. Menurut Fani Pechlivani (2012), menyusui merupakan salah satu factor menurunkan kejadian kanker payudara, pada hasil penelitiannya semakin lama periode menyusui, resiko wanita untuk mengalami kanker payudara semakin kecil.

Penyebab kematian ibu di Indonesia tahun 2013, paling tinggi adalah perdarahan $(30,3 \%)$, diikuti urutan kedua hipertensi $(27,1 \%)$, 
lain-lain $(40.8 \%)$ dan sisanya adalah infeksi, partus lama dan abortus. Lain-lain adalah penyebab kematian ibu tidak langsung, penyebab kematian tidak langsung adalah kanker, jantung, ginjal dll. Kanker Payudara menempati urutan nomer 2 (dua) setelah kanker paru-paru. Kanker payudara merupakan penyebab kematian tertinggi pada wanita dengan prosentase $43,3 \%$. Menyusui sampai dengan 1,5 atau 2 tahun merupakan cara paling mudah mengurangi atau mencegah kejadian kanker payudara. Inisiasi menyusu dini merangsang hormon oksitosin yang berdampak meningkatkan kontraksi rahim sehingga membantu pengeluaran plasenta dan mengurangi perdarahan pada ibu, dimana perdarahan sebagai penyebab kematian tertinggi pada ibu saat ini.

Kematian bayi di Jawa Tengah tahun 2014 menurun dibandingkan tahun 2013, terdapat 5666 kasus bayi meninggal pada tahun 2014 atau sekitar 10.08 per $1000 \mathrm{KH}$, untuk kematian balita pada posisi 11.54 per $1000 \mathrm{KH}$, menurun dibandingkan tahun 2013 sebesar 11.80 per 1000 KH. Kematian bayi di Kabupaten Temanggung tahun 2014 ada diurutan ke-4 dari 36 kota dan kabupaten di Jawa Tengah atau sebesar 14.70 per $1000 \mathrm{KH}$, sedangkan kematian balita tahun 2014 di Kabupaten Temanggung ada diurutan ke-7 dari 36 kota dan kabupaten di Jawa Tengah atau sebesar 15.76 per $1000 \mathrm{KH}$. Sedangkan tahun 2014 kematian ibu di Kabupaten Temanggung mengalami peningkatan yang tajam di bandingkan tahun 2013 atau sebesar 127.16 per $100.000 \mathrm{KH}$, pada tahun 2013 sebesar 62.34 per
100.000 KH. Menurut Indikator Kesehatan Rakyat Kabupaten Temanggung tahun 2015, bayi yang pernah di susui di Kabupaten Temanggung sebesar 96.91\%, kondisi ini tidak jelas apakah bayi disusui secara ekslusif atau tidak. Sedangkan, cakupan ASI ekslusif untuk bayi 0-6 bulan di Kecamatan Parakan sebesar 78,5\%. Kematian ibu di Kabupaten Temanggung pada tahun 2014 mengalami peningkatan yang sangat drastis dibandingkan tahun tahun sebelumnya, pada tahun 2014 adalah 127.16 per $100.000 \mathrm{KH}$ dan tahun 2013 adalah 62.34 per 100.000 KH.Penyebab kematian ibu di Kabupaten Temanggung adalah pre-eklamsia sebesar 33\%, perdarahan sebesar $11 \%$ dan lain-lain sebesar 58\%. Menyusui secara ekslusif yang dilanjutkan sampai dengan bayi berusia 2 tahun mempunyai pengaruh yang sangat besar bukan hanya untuk bayi saja tetapi juga untuk kesehatan dan keselamatan ibu.

Pemberian ASI ekslusif dan dilanjutkan pemberian ASI sampai anak berusia 2 tahun, merupakan langkah yang tepat dalam menurunkan angka kematian bayi, balita dan ibu di Kabupaten Temanggung. Selain itu menyusui dalam waktu yang lama dapat menurunkan angka kematian ibu akibat perdarahan pasca melahirkan, kanker payudara dan kanker ovarium. Partisipasi masyarakat dalam mendukung gerakan menyusui secara ekslusif yang dilanjutkan sampai anak berusia 2 tahun sangat dibutuhkan. 


\section{Rumusan Masalah}

Masyarakat adalah sumberdaya

yang terbesar, untuk itu masyarakatlah yang menjadi aktor dan penentu pembangunan. Keterlibatan masyarakat dalam mengenali masalah dilingkungannya sangat menentukan keberhasilan suatu program. Hasil studi pendahuluan didapatkan data, bayi yang pernah di susui di Kabupaten Temanggung sebesar 96.91\%, kondisi ini tidak jelas apakah bayi disusui secara ekslusif atau tidak. Sedangkan cakupan ASI ekslusif pada bayi 0-6 bulan di Kecamatan Parakan sebesar $78,5 \%$. Wawancara kepada 10 ibu menyusui 4 ibu menyusui bayinya secara eklusif, dan 6 ibu menyusui bayinya tidak ekslusif. Wawancara kepada keluarga ibu menyusui didapatkan data 5 keluarga mendukung ibu menyusui bayinya secara ekslusif dan 5 keluarga tidak mendukung ibu menyusui bayinya secara ekslusif. 3 kader melakukan penyuluhan ASI ekslusif kepada ibu menyusui yang datang ke Posyandu, 7 kader hanya mengingatkan kepada ibu menyusui untuk terus menyusui bayinya. Salah satu kegiatan Puskesmas Parakan adalah program ASI ekslusif. Puskesmas sering melakukan pertemuan dengan kader, kelurahan, kecamatan dan pihak terkait membahas banyak hal salah satunya sosialisasi ASI ekslusif. Partisipasi masyarakat dalam program ASI ekslusif sangat menentukan keberhasilan program ini. Oleh karena itu dapat dirumuskan "Bagaimana tingkat partisipasi masyarakat (pemerintah dan masyarakat) dalam program ASI ekslusif di Kecamatan Parakan Kabupaten Temanggung?

\section{METODE PENELITIAN}

Penelitian ini menggunakan pendekatan kualitatif dengan metode deskriptif. Dimana pengungkapan data atau fakta dengan cara nonstatistik dan menggambarkan keadaan yang sebenarnya sesuai dengan kondisi lapangan. (Ibrahim, 2015). Metode pengumpulan data yang dilakukan peneliti dengan teknik observasi, dokumen dan wawancara mendalam. Teknik observasi yang dilakukan peneliti bertujuan melihat kehidupan sosial masyarakat Parakan, relasi yang dibangun semua pihak. Peneliti juga melakukan pemetaan kawasan (mapping area) di wilayah kerja Puskesmas Parakan yang bertujuan untuk mendapatkan gambaran yang jelas bagaimana aktivitas masyarakat, kehidupan sosial dan upaya-upaya atau partisipasi masyarakat dalam mendukung program ASI eksklusif di wilayah kerja Puskesmas Parakan. Peneliti juga menggunakan teknik wawancara mendalam dengan menggunakan pedoman wawancara sebagai intrumen pengumpulan data terkait partisipasi dalam pemberian ASI ekslusif.

Lokasi penelitian di wilayah kerja Puskesmas Parakan Kecamatan Parakan Kabupaten Temanggung meliputi desa Catur Anom, desa Parakan Kauman, desa Parakan Wetan, dengan pertimbangan Puskesmas Parakan sudah menjalankan program ASI ekslusif di Kabupaten Temanggung. Alasan pemilihan tiga lokasi penelitian untuk melihat partisipasi 
masyarakat terhadap program ASI ekslusif yang ada di pinggiran (desa) dan di kota Kecamatan Parakan. Semua masyarakat di wilayah kerja Puskemas Parakan dapat menjadi sumber data, namun karena keterbatasan peneliti dalam bertemu, berdiskusi dan melakukan wawancara mendalam. Untuk itu penulis menentukan beberapa pihak yang memang terlibat langsung dalam pengambilan kebijakan, pelaksana program dan sasaran dari program ASI ekslusif. Sumber data atau informan yang peneliti tetapkan terdiri dari Kepala Puskesmas Parakan, petugas gizi, Kepala Kelurahan, kader, ibu menyusui dan keluarga.

Analisis yang digunakan oleh peneliti dengan menggunakan analisis data kualitatif, dengan prosedur content analysis yang terdiri dari mengumpulkan data, reduksi data, display data (penyajian data) yang disajikan dalam bentuk naratif dan terakhir menarik kesimpulan setelah dilakukan indepth interview terhadap informan (Bungin, 2015).

Triangulasi adalah teknik untuk menvalidasi keakuratan data yang diperoleh baik melalui sumber, penyidik, metode dan teori (Moelong, 2007). Agar validitas data tetap terjaga, penulis melakukan wawancara secara terpisah kepada informan-informan, melakukan observasi lapangan serta menelaah dokumen terkait program ASI Ekslusif (Ibrahim, 2015).

\section{HASIL}

Informan terdiri dari kepala puskesmas, satu petugas gizi, satu bidan, tiga kepala kelurahan, tiga kader kesehatan, tiga ibu menyusui, dan tiga keluarga yang terdiri dari suami. Adapun karakteristik informan sebagai berikut:

1. Kepala Puskesmas adalah seorang dokter umum yang bertanggung jawab terkait seluruh program puskemas, termasuk ASI ekslusif.

2. Kepala Kelurahan ketigatiganya memiliki latar belakang pendidikan sarjana dan sudah memiliki pengalaman cukup lama di bidangnya.

3. Petugas Gizi memiliki latar belakang diploma III dan sudah cukup lama berpengalaman dibidangnya.

4. Kader Kesehatan : dua kader memiliki latar belakang SMA dan satu kader memiliki latar belakang SMP. Pengalaman menjadi kader sudah lebih dari lima tahun.

5. Ibu menyusui, usia ibu sekitar 20- 32 tahun, memiliki latar belakang pendidikan terdiri dari dua orang latar belakang sarjana, satu orang latar belakang SMA, dua orang latar belakang SMP dan satu latar belakang SD. Sebagian besar ibu tidak bekerja, hanya satu ibu yang bekerja sebagai guru SD. Empat ibu memiliki satu anak dan dua ibu memiliki dua orang anak.

6. Keluarga atau suami, memiliki latar belakang pendidikan dua orang berpendidikan sarjana, satu orang perpendidikan diploma III, satu orang perpendidikan SMA, dua orang berpendidikan SMP. Latar belakang pendidikan satu orang PNS (Perawat), tiga orang bekerja sebagai karyawan 
swasta dan dua orang bekerja sebagai buruh.

\section{Perencanaan}

Perencanaan program merupakan proses yang berkelanjutan. Perencanaan program merupakan pernyataan tertulis tentang kegiatankegiatan yang akan dikembangkan secara bersama -sama antara semua warga masyarakat, fasilitator, pembina, pemuda, petugas lapangan dan pemangku kepentingan. Dengan melibatkan masyarakat dalam merumuskan perencanaan program ASI ekslusif, keberhasilan program ASI ekslusif semakin tinggi (Totok, 2015). Dalam perencanaan ini akan dibahas terkait keterlibatan masyarakat dalam perencanaan program, strategi, pelaksana program, sasaran, metode, dan waktu pelaksanaan kegiatan.

\section{Perencanaan Program}

Menurut Ambar (2004) pendekatan bottom-up merupakan pendekatan yang sangat ideal dalam pembangunan, pendekatan ini melibatkan masyarakat dalam perencanaan program dan terlibat langsung dalam pembangunan. Pendekatan ini lebih ideal dibandingkan dengan pendekatan top-down, karena program-program sudah dikemas sedemikian rupa dan masyarakat tinggal menerima apa adanya, sehingga program tidak akan berjalan dengan maksimal. Pemberdayaan merupakan implikasi dari strategi pembangunan yang berbasis pada masyarakat (people centered development) untuk itu perencanaan program perlu melibatkan banyak pihak dalam kegiatan-kegiatan

direncanakan.

Perlu adanya agen pembaharu agar program ini dapat berjalan dengan lancar ( Ambar, 2004). Kelurahan, pemuka agama dan organisasi perpanjangan tangan pemeritah seperti ormas, LSM, organisasi kepemudaan, organisasi wanita, PKK, LMD dan sebagainya. Organisasi diatas sangat dekat dengan masyarakat. Organisasi ini dapat menjadi agen pembaharu, selain itu sangat menguasai social maping dalam masyarakat yang akan diberdayakan.

Hasil penelitian belum ada agen pembaharu, belum ada keterlibatan ormas, LSM, organisasi pemuda, pemuka agama dalam perencanaan program maupun pelaksanaan program ASI ekslusif. Hanya PKK yang terlihat dalam ASI ekslusif, namun belum optimal dalam pelaksanaannnya karena lebih sekedar mengingatkan ibu-ibu untuk menyusui bayinya. Sedangkan kelurahan sebagai pengerak PKK memiliki peranan yang penting dalam membantu menyukseskan program ASI ekslusif, namun tidak semua kelurahan sebagai pengerak PKK memiliki perencanaan terkait program ASI. Selain itu didalam merencanakan program ASI ekslusif, kepala Puskesmas Parakan hanya mengikuti program yang sudah berjalan dari Dinas Kesehatan Kabupaten Temanggung dan peraturan pemerintah yang sudah berjalan terkait ASI ekslusif. Tidak ada penyusunan rencana program ASI ekslusif bersama dengan masyarakat. Hal ini tampak dari hasil wawancara dengan seorang informan 
terkait rencana pelaksanaan program ASI ekslusif:

"Kalau untuk perancangan program kita mengikuti dari dinas kesehatan Temanggung dan peraturan pemerintah tentang ASI ekslusif. Kita belum melibatkan organisasi pemuda, LSM maupun pemuka agama dalam kegiatan ASI ekslusif,",(KP)

"Pertemuan dengan kader, bu camat, Dandim, dan kelurahan sering kita lakukan, tapi tidak menyusun program ASI ekslusif, kalau ketemu ya banyak yang kita bicarakan bu, salah satunya ya pentingnya ASI ekslusif "'(PG)

"Kalau kegiatan di kelurahan terkait ASI kok gak ada ya, kelurahan hanya penggerak PKK saja, ya seperti dukungan ke Posyandu saja bu, kalau laporan-laporan kita langsung ke Puskesmas, selain itu lurahya saja sibuk wong bukan asli Parakan luar Parakan jadi tidak menetap di Parakan jadi kita lebih banyak berhubungan

puskesmas kelurahan"(KDR-3)

\section{Strategi}

Strategi dalam mendukung program ASI ekslusif di wilayah kerja Puskesmas Parakan yaitu melalui upaya-upaya program seperti menyediakan ruang memerah ASI, menyediakan materi penyuluhan dan memberikan penyuluhan kepada ibuibu hamil dan menyusui. Hal ini dapat dilihat dari hasil wawancara dengan informan terkait dengan strategi dari program ASI ekslusif yang dibuat:

"Program yang sudah berjalan ya sosialisasi ASI, kami sediakan juga klinik laktasi biar ibu -ibu bisa menyusui di puskesmas. Kita juga sedang mencanangkan "Puskesmas Ramah Anak"ya bagian dari dukungan terhadap ASI ekslusif. Rencananya kami mau buatkan ruang bermain buat anak-anak disana..." (KP)

"Kita mengundang kaderkader posyandu, PLKB kecamatan dan puskesmas untuk membahas banyak hal salah satunya ASI ekslusif, ada juga pelatihan terkait perawatan payudara biar ASInya lancar nantinya. Tahun 2016 mulai Januari kita punya program gerakan sayang ibu dan anak salah satu program ASI ekslusif." (L-3)

\section{Pelaksana Program}

Pemberdayaan masyarakat hendaknya mengarah pada pembentukan kognitif masyarakat yang lebih baik, dengan kognitif yang baik masyarakat dapat mencari solusi atas permasalahan yang dihadapi. Sosialisasi ASI ekslusif yang berupa penyuluhan di wilayah kerja Puskesmas Parakan lebih sering dilakukan oleh petugas kesehatan yaitu bidan atau petugas kesehatan sedangkan kader lebih berperan dalam pencatatan saja dan mengingatkan ibu-ibu untuk menyusui bayinya. Berikut ini hasil wawancara dengan informan terkait 
siapa yang akan melakukan sosialisasi ASI ekslusif :

"Ya petugas gizi bisa juga bidan dan kader $(P G)$

"Biasane penyuluhan kaliyan bu bidan, kader hanya pencatatan saja".(L1)

"Kalau penyuluhan seringnya ngih bu bidan, petugas gizi jarang datang, kecuali ada laporan balita sing BGM perlu konsultasi terkait PMT, kalau kita kaderya mengingatkan saja ibu-ibu tetap mimiki bayeke pas nimbang " (KDR-2)

"Tidak selalu bidan bisa saja bu perawat" (KDR-3)

\section{Sasaran Program}

Masyarakat sesungguhnya memiliki daya untuk membangun. Schumacher memiliki pandangan"kail jauh lebih tepat daripada ikan". Ada tiga pilar yang harus dipertemukan dalam proses pemberdayaan masyarakat yaitu pemerintah, swasta dan masyarakat yang hendaknya menjalin hubungan kemitraan yang selaras (Ambar 2004). Berikut ini wawancara dengan informan terkait dengan sasaran dari program ASI ekslusif di wilayah kerja Puskesmas Parakan :

"Sasaran program ya ibu hamil dan ibu menyusui" $(K P)$

"Ibu-ibu yang menikah dan hamil diundang ke kelurahahan dijelaskan ASI ekslusif oleh bu Darwati, ya diberi pelatihan sederhana seperti perawatan payudara dan ASI ekslusif. Kegiatan dilapangan ada rapat $R T$ dan $R W, \quad$ kita mengandeng Puskesmas yang diundang kepala keluarga untuk motivasi ASI ekslusif pak kades pasti datang. "(KDR-3)

Sasaran program ASI ekslusif harus tepat sasaran. Dukungan keluarga dalam program ASI ekslusif sangat penting. Salah satu factor kegagalan dalam pemberian ASI ekslusif adalah keluarga terutama nenek atau simbah yang beranggapan apabila bayi rewel dianggap lapar dan perlu mendapatkan tambahan makanan. Hal ini tampak dari hasil wawancara dengan salah satu informan terkait dukungan keluarga terkait pemberian ASI ekslusif:

" ASI lebih baik dari susu formula, pas usia 5 bulan anak saya diberi makan tambahan (serelac) oleh simbahnya (ibu mertua saya) karena anak saya sering rewel, padahal BB tetap tidak ada penurunan, alasan simbahnya ora warek.(IBM2)

\section{Metode}

Dalam menyukseskan program ASI ekslusif dapat dilakukan dengan banyak cara, antara lain melalui kampanye ASI lewat media elektronik, penyebaran materi KIE ASI dengan membagikan (leaflet, brosur, buku, booklet) atau melakukan kerjasama dengan perusahan-perusahan untuk menyukseskan program ASI bagi ibu bekerja. Berikut ini hasil wawancara dengan informan terkait metode atau 
cara atau upaya yang dilakukan untuk sosialisasi program ASI ekslusif :

"Kita mengundang penggerak $P K K$, perwakilan kader, bu camat, kelurahan, Dandim, PLKB dari kelurahan, PWRI.Kita informasikan terkait materi ASI ekslusif, penyuluhan juga dilakukan kepada ibu-ibu yang hamil dan menyusui di posyandu, leaflet tentang ASI ekslusif juga ada dan kita berikan" $(P G)$

\section{Waktu Pelaksanaan}

Menurut Bungin, pemberdayaan tidak bersifat selamanya melainkan sampai dengan masyarakat mampu untuk mandiri. Pemberdayaan membutuhkan proses belajar sampai mandiri. Tahap pembentukan perilaku sampai dengan peningkatan intelektual, kecakapan keterampilan sehingga terbentuk inisiatif dan kemampuan inovatif untuk mempertahankan kemandirian membutuhkan waktu. Masyarakat harus sering dipaparkan dengan informasi-informasi terkait pentingnya program ASI ekslusif. Semakin sering masyarakat mendengar tentang ASI ekslusif dan manfaat menyusui, pengetahuan masyarakat akan meningkat dan menumbuhkan kesadaran pada masyarakat bahwa ASI ekslusif dapat mencegah kematian bayi dan balita akibat diare maupun infeksi saluran napas bagian atas.

Selain itu wawasan masyarakat meningkat bahwa menyusui juga mempunyai dampak yang besar bagi kesehatan ibu khususnya dalam mencegah terjadinya perdarahan pasca melahirkan, mencegah kanker payudara dan kanker ovarium sebagai penyebab kematian ibu yang sampai sekarang belum dapat diatasi. Bila pola pikir masyarakat semakin meningkat, otomatis masyarakat akan berpartisipasi aktif dalam program ASI ekslusif itu sendiri. Berikut wawancara dengan petugas gizi terkait kapan kegiatan-kegiatan terkait program ASI ekslusif dilakukan:

" Biasanya untuk penyuluhan ya pas di posyandu bu, kalau sosialisasi program ASI terakhir bulan Agustus 2015, kita undang pengerak PKK, kader-kader, kita juga undang bu camat, bu lurah, PWRI dan PLKB, kita beri materi ASI ekslusif agar bisa membantu kita dalam sosialisasi ASI ekslusif" (PG)

"Seringnya di posyandu, atau pas ada kegiatan PKK atau yasinan" $(L-1)$
"Kalau saya biasanya pas tilik bayi, sering saya ingatkan ibu-ibunya (ojo ngaya-ngaya bayine dimimiki wae ora usah dikei dot apa disambung ben sehat). Tapi seringnya ya pas ibu-ibu yang datang ke posyandu" $(K D R-3)$

Hasil penelitian menunjukan sosialisasi program ASI ekslusif belum intens dilakukan. Pertemuanpertemuan khusus membahas tentang ASI ekslusif, jarang dilakukan. Bila ada pertemuan-pertemuan antara puskesmas dengan kader tidak focus kepada ASI ekslusif tetapi membahas topic-topik yang lain 
" Kegiatan yang dilakukan oleh puskesmas terkait ASI untuk tahun ini belum ada, pernah tetapi tahun sebelumnya, kalau kegiatan lainnya sering dilakukan" (KDR-2)

"Setahun sekali kita kaderkader diundang ke Puskesmas, dijelaskan banyak hal tetapi tidak hanya ASI saja bu, topiknya macem-macem seperti : DBD, penyakit anak, posyandu dll, ASI hanya disinggung saja"'(KDR-3)

\section{Pelaksanaan}

Pelaksanaan atau implementasi adalah berbagai kegiatan yang diarahkan untuk merealisasikan tujuan program sesuai dengan peraturan atau kebijakan yang telah ditetapkan (Roro, 2009). Pelaksanaan program ASI ekslusif di wilayah kerja Puskemas Parakan akan ditinjau dari sudut sumber daya manusia, pendanaan, sarana prasarana, metode dan peraturan atau kebijakan yang telah ditetapkan.

\section{Sumber Daya Manusia}

Sumber daya manusia (human capital) menempati kedudukan dan peran yang sangat penting dalam pembangunan. Namun sebagian masyarakat Indonesia masih berkiblat pada perintah, sehingga tinggal menjadi pelaksana saja dan bukan menjadi konseptor. Menurut Totok (2015) setiap masyarakat pasti memiliki daya, akan tetapi kadang mereka tidak menyadari untuk itu masyarakat harus didorong, diberi motivasi dibangkitkan kesadarannya untuk berpartisipasi dalam program ASI ekslusif.

Semakin banyak masyarakat yang terlibat dalam program ini, kegiatan ini akan semakin banyak mendapatkan dukungan dan tujuan program akan tercapai. Puskesmas Parakan perlu melibatkan banyak orang dalam program ASI ekslusif agar semakin banyak masyarakat yang menyadari pentingnya program ASI ekslusif baik bagi anak maupun ibu. Hal ini tampak dari hasil wawancara dengan informan terkait siapa yang terlibat dalam kegiatan ASI ekslusif:

" Bidan desa yang biasanya penyuluhan kalau kader hanya melakukan pencatatan $\operatorname{saja}(L-1)$

"Kalau ada ibu-ibu yang datang ke klinik laktasi ya saya yang memberikan penyuluhan, ya saya merangkap konselor ASI $(P G)$

" Itu sudah diurusi bu bidan dan kader, kita tidak ngurusi “ (L2)

\section{Pendanaan}

Dana secara nyata penting dalam pelaksanaan suatu program pelayanan sosial, demikian juga dengan program ASI ekslusif. Dana khusus untuk kegiatan program ASI ekslusif di wilayah kerja Puskesmas Parakan tidak ada. Hal ini tampak dari hasil wawancara dengan informan terkait alokasi dana program ASI ekslusif

"Dana khusus untuk kegiatan penyuluhan, pelatihan khusus untuk ASI ekslusif tidak ada, 
tetapi ada anggaran untuk beli susu bagi ibu-ibu hamil itu diambilkan dari dana bantuan kesehatan" $(P G)$

Demikian juga di kelurahan alokasi dana khusus untuk kegiatan ASI ekslusif tidak ada.

Dana desa dari pemerintah memang digunakan untuk pembangunan dan kesehatan, namun untuk khusus program ASI ekslusif belum ada masih tercampur dengan kegiatan lainnya. Berikut ini hasil wawancara dengan informan terkait alokasi dana untuk program ASI ekslusif:

Untuk pertemuanpertemuan kita ambilkan dari dana desa untuk PMT ibu hamil supaya ASI lancar.Untuk motivasi kader kita beri seragam dan uang pengganti transport $R p$. 10.000-15.000,- sekali datang, kalau khusus ASI ekslusif tidak ada ya masih campur dengan kegiatankegiatan yang lain"'(L-3)

\section{Media}

Media dalam penyuluhan ASI ekslusif bertujuan agar materi yang disampaikan mudah diterima oleh masyarakat. Media untuk sosialisasi ASI ekslusif yang telah berjalan di posyandu wilayah kerja Puskesmas Parakan dilakukan dengan membuat leaflet terkait ASI eksklusif yang dibagikan kepada ibu-ibu yang datang ke klinik laktasi di puskesmas dan kader agar diberikan kepada ibu hamil dan menyusui di posyandu dan membantu kader dalam mensosialisasikan ASI ekslusif.
Kondisi yang terjadi di lapangan untuk sosialisasi ASI eksklusif, kader lebih cenderung mengingatkan secara langsung kepada ibu-ibu menyusui, kampanye lewat radio tentang ASI belum ada dan masih menjadi wacana, demikian juga dengan pengunaan alat media untuk penyuluhan tidak semua ibu menyusui mendapatkan ketika menimbangkan bayinya di posyandu. Hal ini tampak dari hasil wawancara dengan informan terkait program ASI yang berjalan:

" Untuk kampanye lewat radio memang belum ada, rencananya mau dipasang di pasar Parakan, kalau leaflet biasanya kita berikan pas ibuibu datang ke klinik laktasi pulangnya kita berikan, kita juga berikan ke kader-kader biar bisa diberikan kepada ibuibu yang menyusui pas menimbangkan bayinya di posyandu” (PG)

"Pas nimbang ke posyandu, bu bidan dan kader seringnya mengingatkan untuk mimiki bayinya, untuk gambar-gambar tentang ASI saya kok belum pernah dapat"(IBM-4)

Kader merupakan fasilitator pemberdayaan masyarakat karena berasal dari masyarakat yang secara sukarela (tanpa imbalan) melakukan kegiatan pemberdayaan masyarakat di lingkungannya. Sebagai fasilitator, kader harus dapat menjadi "agen pembaharuan" yaitu menggerakkan masyarakat untuk melakukan perubahan. Namun dalam wawancara dengan salah satu informan, peran kader belum 
menunjukkan sebagai agen pembaharuan, hal ini terlihat dari hasil wawancara dengan salah satu informan terkait bagaiamana kader dan petugas kesehatan dalam menyampaiakan program ASI ekslusif:

"Saya rutin ke posyandu untuk menimbang BB anak saya, tapi tidak semua kader mengarahkan memberi ASI ada juga yang mengarahkan untuk dikasih susu formula saja, tetapi kebanyakan ya mengingatkan untuk memberi ASI eksklusif. Malah dulu pas saya konsultasi BB anak saya yang gak naik-naik malah disarankan diberi susu formula.(IBM-1)

\section{Sarana Prasarana}

Sarana prasarana sangat mendukung suksesnya program ASI ekslusif di wilayah kerja Puskemas Parakan. Sarana prasarana yang telah disediakan oleh Puskesmas Parakan dalam mendukung ASI ekslusif seperti adanya klinik laktasi di puskesmas dan klinik laktasi di pasar Legi Parakan.Berikut ini hasil wawancara dengan informan terkait sarana prasarana yang mendukung program ASI ekslusif di wilayah kerja Puskesmas Parakan :

"Ya disana kami buatkan klinik laktasi biar ibu-ibu bisa menyusui, di pasar Legi Parakan juga ada ini kami lagi tata-tata memindahkan kursi dan kulkas"(KP)

"Saya belum tahu kalau ada tempat untuk menyusui di pasar Legi" $(K-3)$

\section{Peraturan/Kebijakan}

Kegagalan pemberian ASI ekslusif di wilayah kerja Puskesmas Parakan, sangat tinggi pada ibu bekerja dan tinggal dengan orangtua. Hal ini tampak dari hasil wawancara dengan informan:

"Kendala yang sering ya pada ibu yang bekerja atau tinggal sama dengan simbah, bayi rewel ya dikira lapar" $(P G)$

"Sebagian ibu-ibu mendukung ASI ekslusif yang kurang mendukung ibu-ibu yang bekerja alasanya ya minumnya kurang lha,bayinya rewel terus atau ASI tidak keluar"'(KDR-2)

Beli asi, anemia ruang, radio wacana asi, kader undang, leaflet, bagi2kan

"Ya pas anak saya usia 3 bulan saya sambung susu formula lha bagaimana lagi saya harus bekerja, lagian repot"'(IBM-5)

" Tidak masalah wong harus bekerja dari pada kurang. Pinginnya sih diberi ASI,lagian gak ada waktu untuk ambil ASI ke kantor dan nyimpen ASI (K-5)

Tingginya kegagalan ASI ekslusif pada ibu bekerja, perlu disikapi. Pemerintah telah mengeluarkan kebijakan terkait Peraturan Pemerintah No. 33 Tahun 2012 terkait Pemberian ASI Ekslusif, peraturan ini juga mendukung ibu bekerja tetap bisa memberikan ASI ekslusif bagi bayinya, karena dengan ASI yang cukup bayi dapat 
bertumbuh dan berkembang dengan optimal dan tempat bekerja wajib menyediakan fasilitas untuk memerah dan menyusui bayinya.

Mengingat tingginya kegagalan ASI ekslusif pada ibu bekerja, puskesmas perlu melakukan kerjasama atau koordinasi dengan perusahan atau pabrik untuk menyediakan fasilitas klinik laktasi dan tempat penitipan anak, agar wanita bekerja dapat tenang memberikan ASI pada bayinya. Hasil wawancara dengan informan didapatkan data belum ada kerjasama antara pihak Puskesmas dengan perusahan atau pabrik terkait kebijakan menyediakan klinik laktasi dan penitipan anak:

"Belum ada kerjasama
dengan perusahan-pabrik
terkait program ASI ekslusif"
$(B D N)$

\section{Evaluasi}

Evaluasi program ASI ekslusif adalah kegiatan pemantauan atau pengamatan dari kegiatan program ASI ekslusif yang sudah berjalan. Evaluasi sebenarnya proses yang berkelanjutan dan melekat dalam perencanaan program, evaluasi yang dilakukan meliputi evaluasi proses dan hasilnya. Hasil pemantauan atau pengamatan program ASI ekslusif di wilayah kerja Puskemas Parakan secara umum berjalan dengan baik, hal ini dapat dilihat dari hasil cakupan ASI ekslusif di kecamatan Parakan yang mencapai $80.3 \%$.

Interpretasi cakupan pemberian ASI ekslusif di Indonesia berbedabeda tergantung definisi dan metode pengumpulan data yang digunakan. Penggunaan metode recall 24 jam selalu lebih tinggi dari pada data actual dipopulasi. Hal ini dapat menimbukan asumsi cakupan pemberian ASI ekslusif sudah melebihi target yang ditentukan di tingkat nasional dan dapat melemahkan upaya dari program ASI ekslusif yang digalakan oleh pemerintah (Yekti, 2011). Selain itu bayi yang mendapatkan ASI ekslusif sampai dengan 6 bulan akan berbeda tingkat kesehatannya dibandingkan dengan bayi yang pernah disusui.

Berikut ini hasil wawancara dengan informan terkait bagaimana dengan cakupan ASI eksluisf di wilayah kerja Puskemas Parakan:

"Cakupan ASI Ekslusif di kecamatan parakan sekitar $80,3 \%$, untuk cakupan tiap kelurahan memang berbedabeda, ada yang baik tetapi ada juga yang belum maksimal ( $P G)$

Banyak faktor yang menyebabkan program ASI ekslusif tidak berjalan sesuai harapan. Dukungan masyarakat sangat mendukung keberhasilan program ASI ekslusif. Faktor atau kendala dari program ASI ekslusif di wilayah kerja Puskesmas Parakan disebabkan oleh ibu bekerja dan kurangnya dukungan keluarga terutama nenek atau simbah dalam pemberian ASI ekslusif. Berikut ini hasil wawancara dengan informan terkait kendala dari program ASI ekslusif:

"Kendala kegagalan ASI seringnya pada ibu bekerja atau tinggal bersama dengan nenek atau simbahnya, kalau bayi rewel dianggap lapar" $(P G)$ 
"Ibu yang bekerja kurang merespon bila kita ingatkan untuk mimiki bayinya beda sekali dengan ibu yang tidak bekerja (KDR-1)

Rencana tindak lanjut dari program ASI ekslusif di wilayah kerja Puskesmas Parakan adalah dengan meningkatkan sosialisasi dan meningkatkan kerjasama dengan banyak pihak baik kelurahan maupun kecamatan. Berikut ini hasil wawancara dengan informan terkait rencana tindak lanjut dari program ASI ekslusif kedepan.

"Ya sosialisasi ASI ekslusif akan kita tingkatkan pastinya kerjasama dengan banyak pihak kita tingkatkan juga" $(P G)$

\section{KESIMPULAN}

Hasil penelitian menunjukkan dari segi perencanaan puskesmas masih mengacu pada strategi program ASI ekslusif yang ditetapkan oleh pemerintah pusat dan belum ada pengembangan strategi baru, ada pertemuan-pertemuan tetapi tidak fokus pada materi ASI ekslusif.

Pada pelaksanaan kegiatan, belum banyak masyarakat yang dilibatkan dalam sosialisasi program ASI. Sosialisasi pelaksanaan program sering dilakukan oleh bidan atau petugas kesehatan sedangkan peran kader lebih kearah mengingatkan ibu-ibu untuk menyusui dan melakukan pencatatan, media terutama leaflet belum semua ibu hamil dan menyusui mendapatkan. Belum ada alokasi dana khusus untuk kegiatan program ASI ekslusif.
Pada evaluasi pelaksanaan kegiatan, penyebab kegagalan ASI paling tinggi pada ibu bekerja dan keluarga terutama simbah. Perlunya meningkatkan keterlibatkan masyarakat lebih luas, kerjasama dengan tokoh masyarakat, tokoh agama, karang taruna dalam sosialisasi ASI ekslusif. Perlunya ada kebijakan pengalokasian dana desa untuk sosialisasi ASI ekslusif, intensitas pertemuan-pertemuan terkait materi ASI ekslusif kepada kader lebih ditingkatkan, agar kader bisa ikut membantu melakukan penyuluhan tidak sekedar mengingatkan saja dan perlunya kerjasama dengan perusahan atau pabrik terkait kebijakan menyediakan ruangan untuk memerah dan menyusui bayi. Kampanye lewat radio dapat direalisasikan tidak hanya di pasar Legi Parakan tetapi juga di pusat keramaian lainnya di Parakan.

\section{DAFTAR PUSTAKA}

America Cancer Society. (2016). Cancer Breast. Atlanta Ga: America.

Allison Stuebe. (2009). The Risks of Not Breastfeeding for Mothers and Infants VOL. 2 NO. 4 Reviews In Obstetrics \& Gynecology 223.

Ambar Teguh. (2004). Kemitraan Dan Model-Model

Pemberdayaan. Yogyakarta: Gava Media.

Bappeda. (2015). Indikator Kesehatan Rakyat Kabupaten Temanggung 2015. Temanggung.

Bungin Burhan. (2015). Analisis Data Penelitian Kualitatif : Pemahaman Fisiologis dan 
Metodologis ke Arah

Penguasaan Model Aplikasi.

Jakarta: PT Raja Grafindo

Persada.

Cesar G Victora . (2015). Ment of

Nursing A: Technological

Educational Institute of Athens.

Lancet.

Dinas Kesehatan Kabupaten Temanggung. (2014). Profil Kesehatan Kabupaten Temanggung Tahun 2014.

Departemen Kesehatan. (2014). Profil Kesehatan Indonesia 2014. Jakarta.

Departemen Kesehatan. (2014). Profil Kesehatan Indonesia 2014. Jakarta.

Dinas Kesehatan Provinsi Jawa Tengah. (2015). Kebijakan Dan Strategi Dalam Akselerasi AKI Dan AKB di Jawa Tengah. Semarang.

Departemen Kesehatan RI. (2015). Infodatin: Mari Dukung! Menyusui dan Bekerja.Pusat Data dan Informasi Kementerian Kesehatan RI. ISSN 2442-7659.

Ekowati, Lilik. (2009). Perencanaan Implementasi \& Evaluasi Kebijakan atau Program, Suatu Kajian Teoritis dan Praktis. Surakarta: Pustaka Cakra.

Ibrahim. (2015). Metodologi Penelitian Kualitatif. Bandung: Alfabeta.

Kementerian PPN/Bappenas. (2015). Laporan Pencapaian Pembangunan Milenium di Indonesia 2014. Jakarta: Sekretariat MDGs.

Kementerian Kesehatan RI. (2015). Situasi Penyakit Kanker.
Jakarta: Buletin jendela data dan informasi kesehatan.

Kementerian Kesehatan RI. (2014). “ Situasi Dan Analisis ASI Ekslusif" 1- 7 Agustus Pekan ASI Internasional. Jakarta: Pusat Data Dan Informasi Kementerian Kesehatan RI.

Moeloeng. (2007). Metodologi Penelitian Kualitatif. Edisi Revisi. Bandung: PT Remaja Rosdakarya Offset.

Pechlivani, Fani. (2012). Breastfeeding and breast cancer. Health Scince Journal.Volume 6,Issue 4 (Oktober-Desember 2012). Institute of Athens

Rusli, Utami. (2012). Panduan Inisiasi Menyusu Dini. Jakarta: Pustaka Bunda.

Republik Indonesia. (2012). PP no 33 tahun 2012. Pemberian Air Susu Ibu Ekslusif. Jakarta: Sekretaris Negara.

The Lancet. (2015). Women's, children's, and adolescents' health: who will lead?. Volume 385 Number 9966 January 31, 2015.

Totok, Poerwoko. (2015) . Pemberdayaan Masyarakat: Dalam Perspektif Kebijakan Publik.Edisi Revisi. Bandung: Alfabeta.

Unicef Indonesia. (2012). Ringkasan Kajian Kesehatan Ibu dan Anak.

Yekti, Widodo. (2011). Data Survey dan Laporan Cakupan Pemberian ASI ekslusif: Akuransi dan Interpretasi. Jakarta: Puslitbang Gizi. 